Prepared in cooperation with the U.S. Environmental Protection Agency and the Franklin County Soil and Water Conservation District Data

\title{
Visualization of Soil-Moisture Change in Response to Precipitation Within Two Rain Gardens in Ohio
}

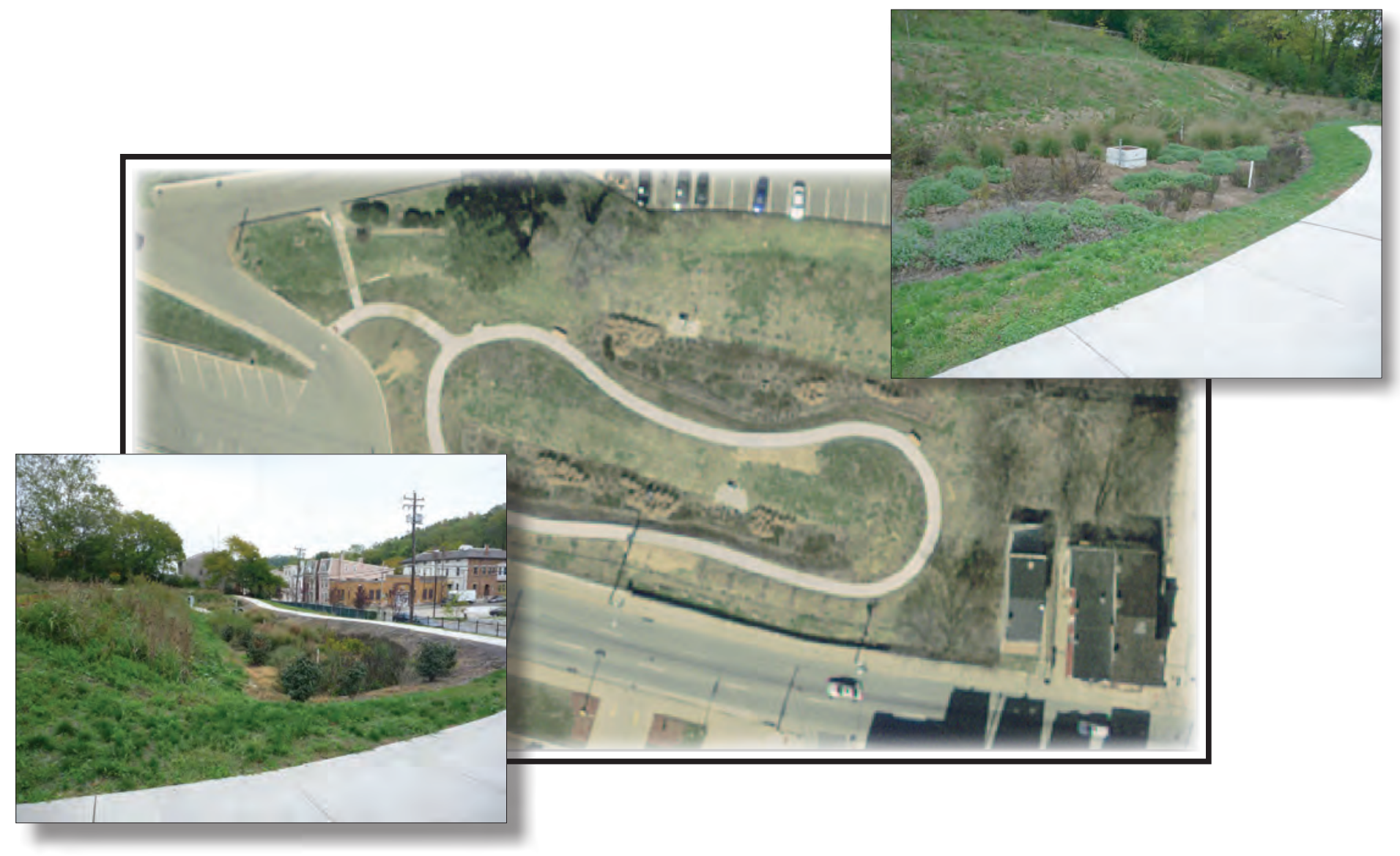

Data Series 837 
Cover: Upper and lower rain gardens at St. Francis site in Cincinnati, Ohio, October 2012. 


\section{Visualization of Soil-Moisture Change in Response to Precipitation Within Two Rain Gardens in Ohio}

By Denise H. Dumouchelle and Robert A. Darner

Prepared in cooperation with the U.S. Environmental Protection Agency and the

Franklin County Soil and Water Conservation District Data

Data Series 837 


\title{
U.S. Department of the Interior SALLY JEWELL, Secretary
}

\section{U.S. Geological Survey Suzette M. Kimball, Acting Director}

\author{
U.S. Geological Survey, Reston, Virginia: 2014
}

For more information on the USGS - the Federal source for science about the Earth, its natural and living resources, natural hazards, and the environment, visit http://www.usgs.gov or call 1-888-ASK-USGS.

For an overview of USGS information products, including maps, imagery, and publications, visit http://www.usgs.gov/pubprod

To order this and other USGS information products, visit http://store.usgs.gov

Any use of trade, firm, or product names is for descriptive purposes only and does not imply endorsement by the U.S. Government.

Although this information product, for the most part, is in the public domain, it also may contain copyrighted materials as noted in the text. Permission to reproduce copyrighted items must be secured from the copyright owner.

Suggested citation:

Dumouchelle. D.H., and Darner, R.A, 2014, Visualization of soil-moisture change in response to precipitation within two rain gardens in Ohio: U.S. Geological Survey Data Series 837, 9-p. pamphlet, 2 video files, $h$ ttp://dx.doi. org/10.3133/ds837.

ISSN 2327-638x (online)

http://dx.doi.org/10.3133/ds837 


\section{Contents}

Abstract
Introduction
Purpose and Scope
St. Francis Site, Cincinnati
Griggs Reservoir Site, Columbus
Dethods and Visualization
St. Francis Site, Cincinnati
Refiggs Reservoir Site, Columbus

\section{Figures}

1. Aerial image of the St. Francis site, Cincinnati, Ohio.....................................................

2. Aerial image of the upper and lower rain gardens, St. Francis site,

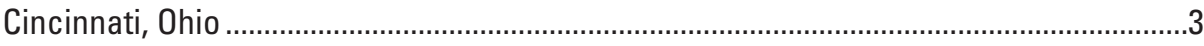

3. Upper $(A)$ and lower $(B)$ rain gardens at St. Francis site in Cincinnati, Ohio,

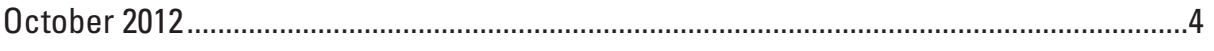

4. Aerial image of the Griggs Reservoir site, Columbus, Ohio............................................

5. $A$, Wireless soil-moisture probe. $B$, Photo showing a nest of moisture sensors installed at three depths.................................................................................................

\section{Tables}

1. Precipitation and flow-volume totals at St. Francis site, September 2012 ......................8

2. Precipitation and flow-volume totals at Griggs site, December 2012 ..............................

Visualizations [available for downloading at http://pubs.usgs.gov/ds/0837/animation]

1. Animation of changes in soil moisture at three depths in the rain garden at the St. Francis site, Cincinnati, Ohio, September 2012.

2. Animation of changes in soil moisture in the rain garden at the Griggs Reservoir site, Columbus, Ohio, December 2012. 


\section{Conversion Factors}

\begin{tabular}{lcl}
\hline \multicolumn{1}{c}{ Multiply } & By & \multicolumn{1}{c}{ To obtain } \\
\hline centimeter $(\mathrm{cm})$ & Length & \\
inch (in.) & 0.3937 & inch (in.) \\
inch (in.) & 2.54 & centimeter $(\mathrm{cm})$ \\
foot (ft) & 25.4 & millimeter $(\mathrm{mm})$ \\
\hline & 0.3048 & meter $(\mathrm{m})$ \\
\hline square inch $\left(\mathrm{in}^{2}\right)$ & Area & \\
square foot $\left(\mathrm{ft}^{2}\right)$ & 6.452 & square centimeter $\left(\mathrm{cm}^{2}\right)$ \\
square foot $\left(\mathrm{ft}^{2}\right)$ & 929.0 & square centimeter $\left(\mathrm{cm}^{2}\right)$ \\
acre & 0.09290 & square meter $\left(\mathrm{m}^{2}\right)$ \\
\hline & 0.4047 & hectare $($ ha) \\
\hline cubic foot $\left(\mathrm{ft}^{3}\right)$ & Volume & \\
cubic foot $\left(\mathrm{ft}^{3}\right)$ & 28.32 & cubic decimeter $\left(\mathrm{dm}^{3}\right)$ \\
\hline
\end{tabular}




\title{
Visualization of Soil-Moisture Change in Response to Precipitation Within Two Rain Gardens in Ohio
}

\author{
By Denise H. Dumouchelle and Robert A. Darner
}

\begin{abstract}
Stormwater runoff in urban areas is increasingly being managed by means of a variety of treaments that reduce or delay runoff and promote more natural infiltration. One such treatment is a rain garden, which is built to detain runoff and allow for water infiltration and uptake by plants. Water flow into or out of a rain garden can be readily monitored with a variety of tools; however, observing the movement of water within the rain garden is less straightforward. Soil-moisture probes in combination with an automated interpolation procedure were used to document the infiltration of water in two rain gardens in Ohio. Animations show changes in soil moisture in the rain gardens during two precipitation events. At both sites, the animations demonstrate underutilization of the rain gardens.
\end{abstract}

\section{Introduction}

Managing stormwater runoff from urban areas is increasingly being addressed by using a low-impact development (LID) approach to reduce or delay runoff by minimizing impervious areas and promoting more natural infiltration. A variety of best management practices (BMPs) typically are used at LID sites; for example, rain gardens, bioretention features, or porous pavers (Dietz, 2007). Monitoring the hydraulic characteristics of LID features is important for understanding how water moves through the features and for demonstrating the effectiveness of the overall design. In addition to monitoring of the inflow and outflow of water, monitoring water movement within the system provides important information on system performance. For example, observing water flow into and out of rain gardens, which are intended to capture runoff and allow some or all of the water to infiltrate into the soils, can be relatively easy depending on the design; however, observing the movement of water within the rain garden is less straightforward. Soil-moisture probes in combination with an automated interpolation procedure are one tool for observing the movement of water within rain gardens. The U.S. Geological Survey (USGS), in cooperation with the U.S. Environmental Protection Agency, Office of Research and Development, and the Franklin County (Ohio) Soil and Water Conservation District, is conducting a series of investigations to develop and implement a hydrometric monitoring system for rain gardens. Data from these studies will be used to understand how water moves through a variety of rain garden designs.

\section{Purpose and Scope}

This report describes the use of soil-moisture probes in two Ohio rain gardens, one in Cincinnati and the other in Columbus. At the Cincinnati site, data from two precipitation events in September 2012 are presented. At the Columbus site, data from two events in December 2012 are presented. An automated procedure was used to create animations that show the changes in soil moisture over time within the rain gardens.

\section{Site Descriptions}

\section{St. Francis Site, Cincinnati}

At the St. Francis Apartments along Queen City Avenue in Cincinnati, Ohio, the city contracted for the installation of a two-stage, stepped rain garden as part of the reconstruction of a parking lot. The rain garden was designed to reduce stormwater runoff and provide filtration to improve water quality. The site is sloped; there is a wooded area above a parking lot and a grassed area below the parking lot. The rain garden is at the bottom of the slope (fig. 1) and is divided into two units (figs. 2 and 3), which are hereafter referred to as the "upper" and "lower" rain gardens.

The upper rain garden receives water from precipitation that falls directly on the garden and overland runoff from the wooded slope that drains to the parking lot and from there to the upper rain garden via a 12-inch (in.) culvert. This drainage area is about 94,500 square feet $\left(\mathrm{ft}^{2}\right)(2.2$ acres), although an undetermined volume of the overland flow from this area is lost as runoff down the access road. The grassed slope 


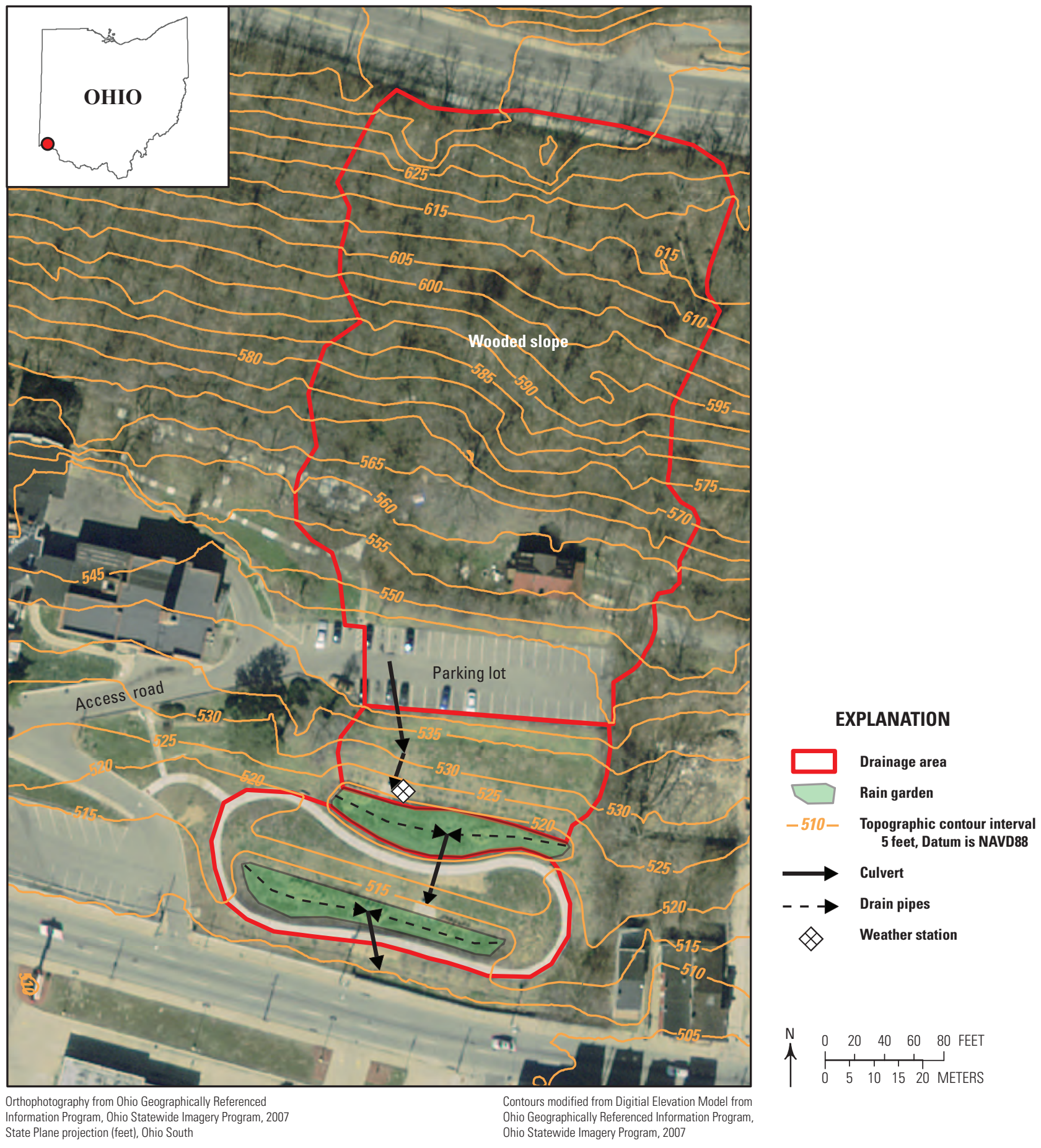

Figure 1. Aerial image of the St. Francis site, Cincinnati, Ohio. 


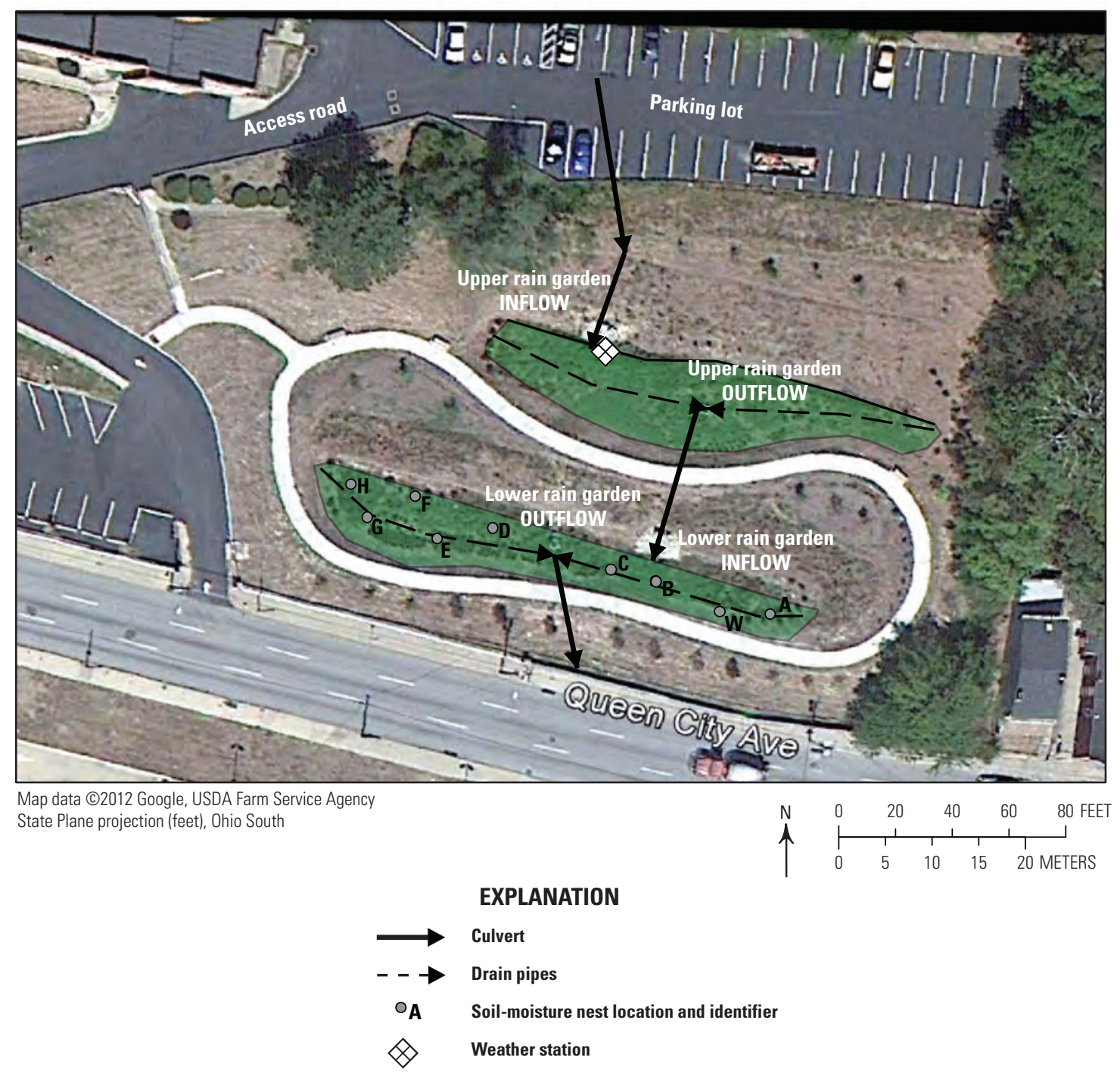

Figure 2. Aerial image of the upper and lower rain gardens, St. Francis site, Cincinnati, Ohio. 


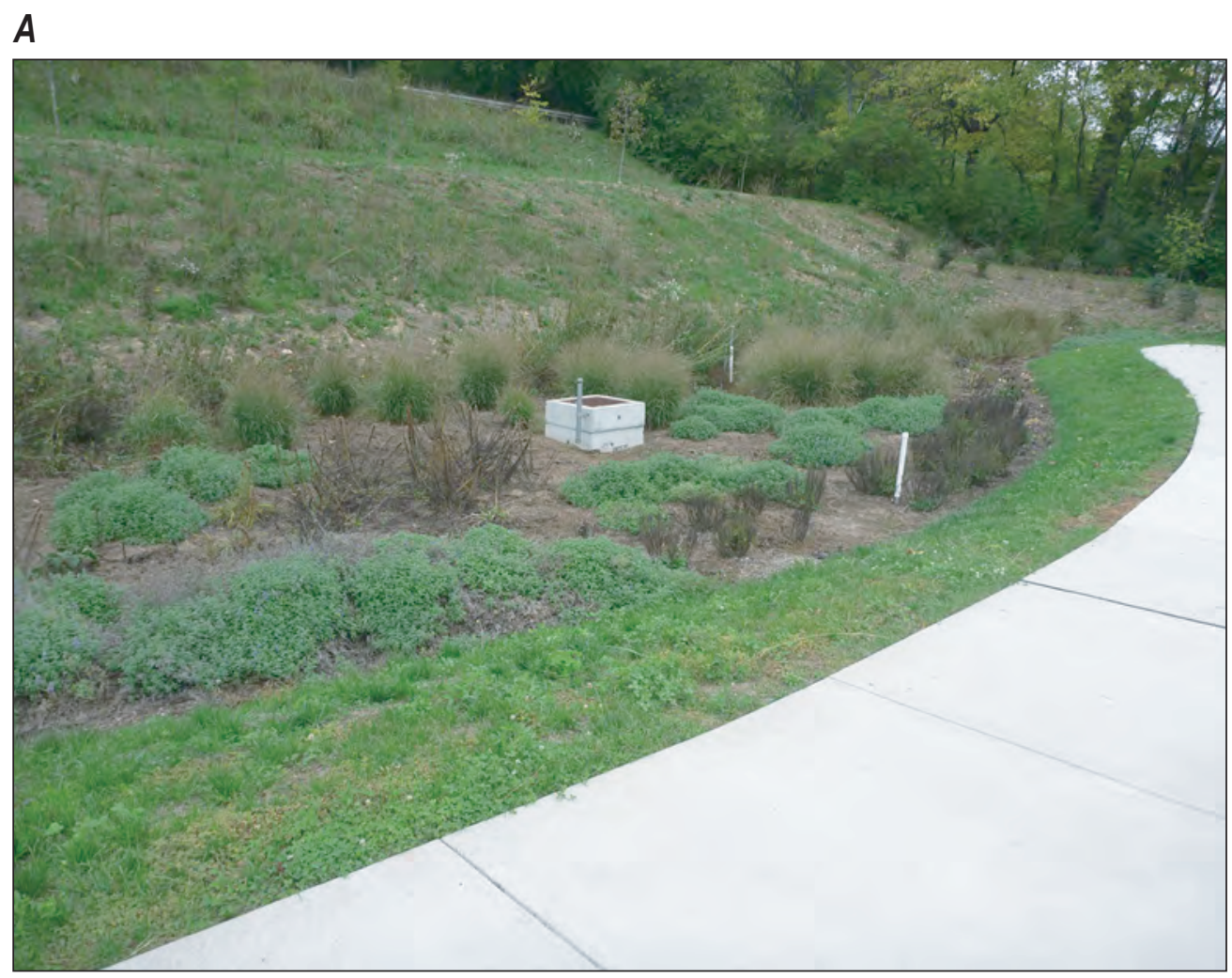

\section{B}

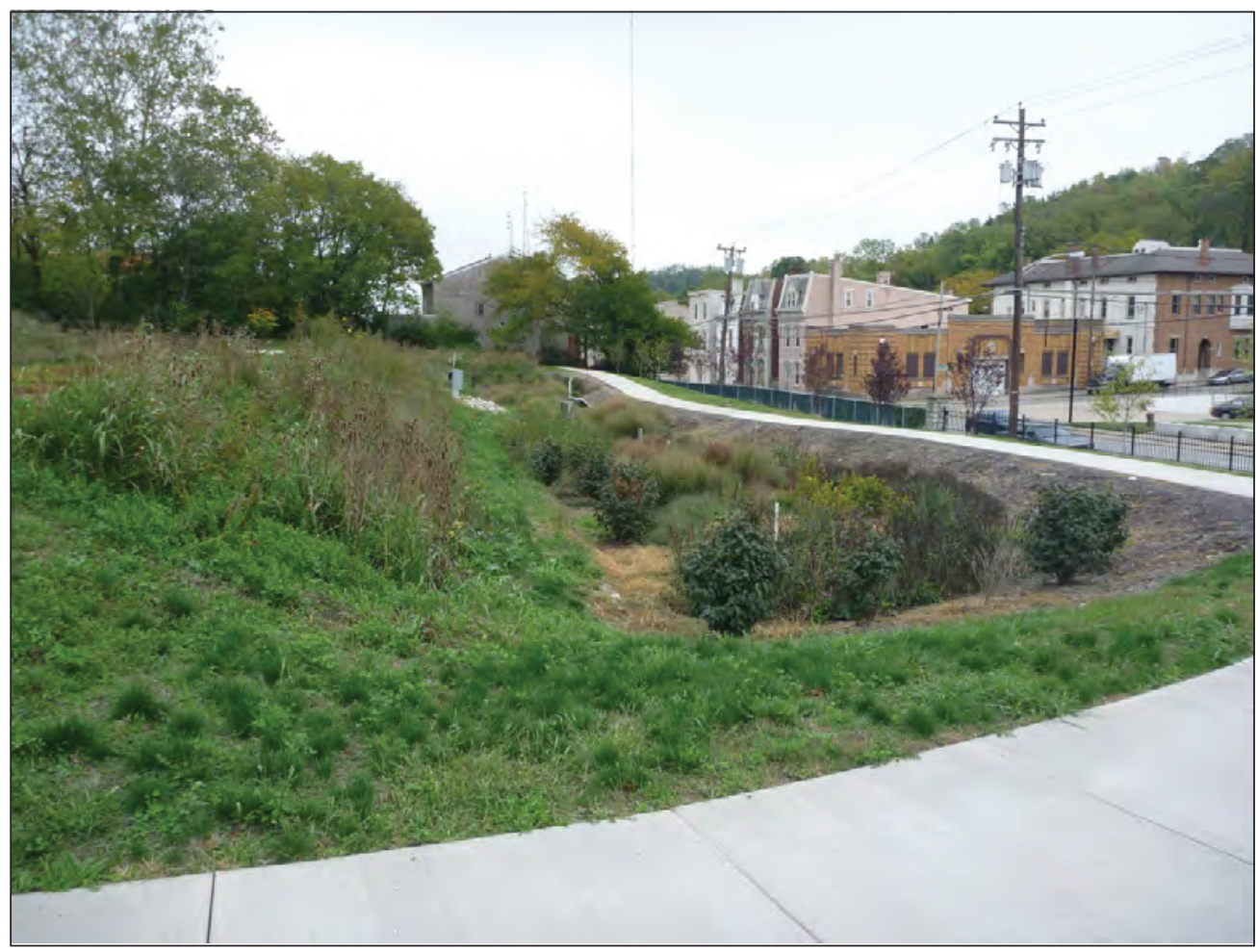

Figure 3. Upper $(A)$ and lower $(B)$ rain gardens at the St. Francis site in Cincinnati, Ohio, October 2012. 
below the parking lot also drains to the upper rain garden via overland runoff; this drainage area is about $12,000 \mathrm{ft}^{2}(0.28$ acre). The lower rain garden receives direct precipitation, any discharge from the upper rain garden, and overland runoff from the approximately $15,300 \mathrm{ft}^{2}(0.35$ acre $)$ of grassed slope and sidewalk between the upper and lower rain gardens.

The rain gardens were constructed by excavating a bowl-shaped depression into the silty clay loam soil (Lerch and others, 1982). The bottom of the depression was filled with about 1 foot ( $\mathrm{ft}$ ) of gravel, and a geotextile liner was laid over the gravel to reduce the downward migration of fine sediments. Above the liner, about $2 \mathrm{ft}$ of engineered soil (a sand, soil, and compost mixture) was used to fill in the remainder of the excavation. In both gardens, a 6-in.diameter perforated polyvinyl chloride (PVC) drain pipe was installed in the gravel layer. The drain in the upper rain garden discharges to the surface of the lower garden. The drain in the lower garden discharges to a storm-sewer pipe and, to prevent flooding, there is also an overflow grate raised slightly above the surrounding grade that drains to the same storm-sewer pipe. A crest-stage gage at the overflow grate records maximum surface-water elevations during a rainfallrunoff event (Sauer and Turnipseed, 2010); the elevation of the overflow grate is known, so events that cause surface water to move through the overflow can be determined. Flumes inserted in the culverts are used to measure the inflows and outflows from each garden (Kilpatrick and Schneider, 1983). The upper rain garden has a surface area of about $3,600 \mathrm{ft}^{2}$ and the lower, about 3,300 $\mathrm{ft}^{2}$.

The lower rain garden was chosen for the soil-moisture study because the engineered soil mixture contained more topsoil, and field observations noted more ponded water and faster plant growth compared to the upper rain garden. In addition, because of the transit through the upper rain garden, the inflow to the lower garden is less flashy.

\section{Griggs Reservoir Site, Columbus}

Griggs Reservoir in Columbus, Ohio, is one of three water-supply reservoirs serving the City of Columbus. In Griggs Reservoir Park, between Riverside Drive and the edge of the reservoir, the city contracted for the installation of multiple rain gardens to reduce the amount of urban runoff entering the reservoir. The rain garden monitored in this study receives runoff through two culverts that discharge into the garden near its south end (fig. 4). One of the two culverts drains stormwater runoff from a commercial lot of about $204,700 \mathrm{ft}^{2}$ (4.7 acres), and the other drains a residential neighborhood of about $1,302,400 \mathrm{ft}^{2}$ (29.9 acres). The rain garden is similar in design to the one at the St. Francis site, but it is shallower (owing to near-surface, underlying carbonate bedrock), and it contains only 1 to $11 / 2 \mathrm{ft}$ of engineered soil above the geotextile liner. A drainpipe in the gravel base and a raised overflow grate at north end of the rain garden route excess water directly to the reservoir. A crest-stage gage at the overflow grate records maximum surface-water elevations during a rainfall-runoff event; the elevation of the overflow grate is known, so events that cause surface water to move through the overflow can be determined. Because the garden was built on a hillside, a retaining wall was constructed along the edge opposite the inflows. The rain garden is about 8,500 $\mathrm{ft}^{2}$ in surface area. 


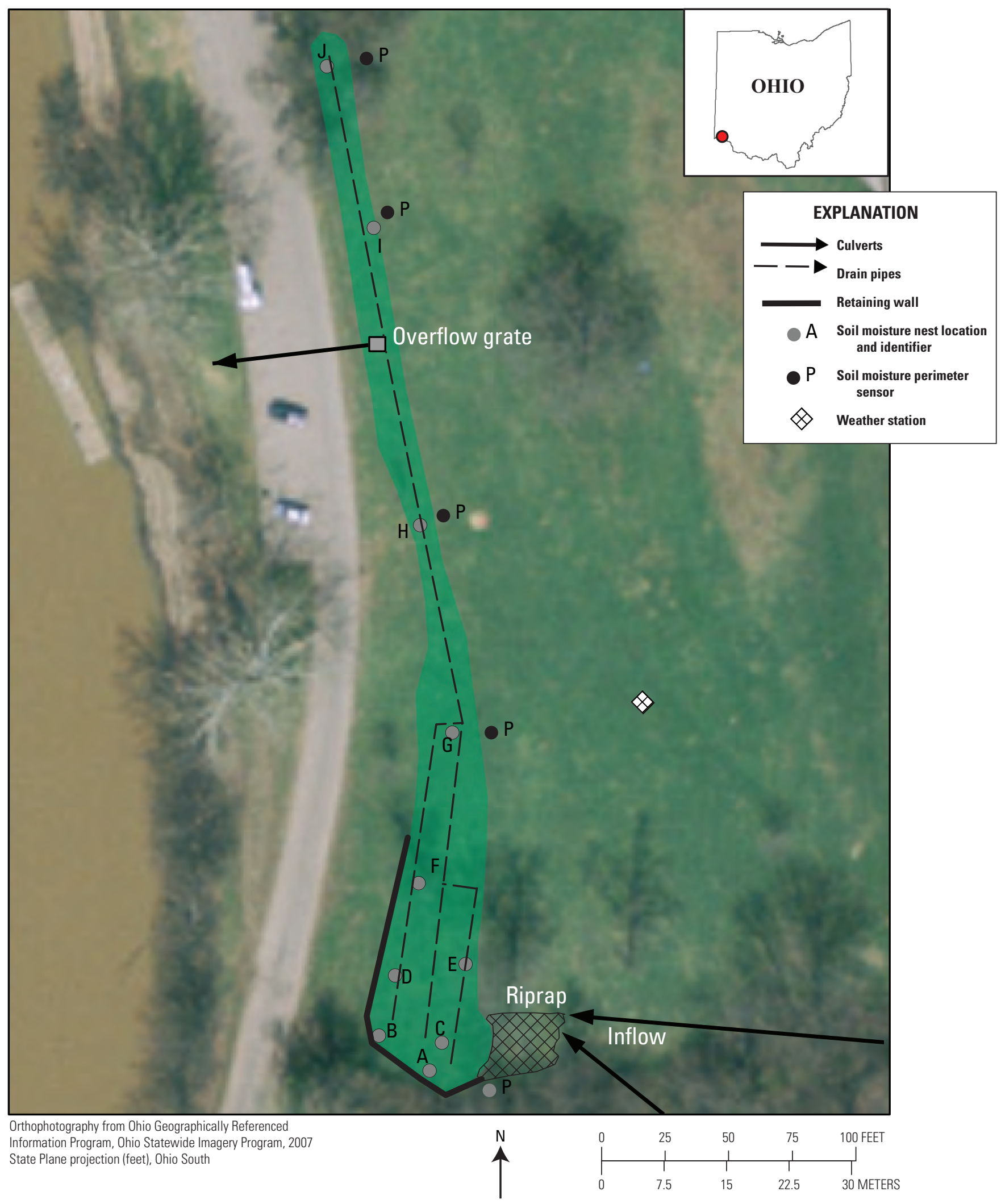

Figure 4. Aerial image of the Griggs Reservoir site, Columbus, Ohio. 


\section{Methods}

The soil-moisture sensors used at both sites (Campbell Scientific models CWS655 (fig. 5A) and CS616; http://www. campbellsci.com/soil-water-content) measure volumetric water content from zero percent to saturation. The sensors have two fixed tines that are inserted into the soil; tines on the CWS655 are 15 centimeters (cm; 5.9 in.) long, and those on the CS616 sensor are $30 \mathrm{~cm}$ (11.8 in.)long. The CWS655 communicates with a Campbell Scientific CR1000 data logger wirelessly and was observed to lose data during times of communication difficulties, whereas the CS616 sensor is hard wired to a data logger and communication is therefore more reliable.

At the St. Francis site, nine soil-moisture nests were installed in the lower rain garden. Each nest consists of three sensors with the tines positioned horizontally at about 0.5 , 1 , and $2 \mathrm{ft}$ below the surface (fig. $5 B$ ). The deepest sensor is about $0.2 \mathrm{ft}$ above the geotextile liner. The location of each nest was surveyed (fig. 2). Each sensor was configured to record data hourly.

At the Griggs Reservoir site, 10 nests of soil-moisture sensors were installed at depths of 0.5 and $1 \mathrm{ft}$, with an additional 5 sensors scattered around the perimeter at a depth of $0.5 \mathrm{ft}$. The location of each sensor was surveyed (fig. 4). Each sensor was configured to record data every 30 minutes.

Precipitation data were measured by use of tippingbucket rain gages at weather stations at each site. These gages are operated and maintained by the USGS.

The soil-moisture data were imported into ArcGIS 10.0 (Esri, Redlands, California). For the St. Francis data, a script was written to separate moisture data values for the three different sensor depths: surface ( 0.5 - $\mathrm{ft}$ depth), $1-\mathrm{ft}$, and $2-\mathrm{ft}$ depths. For the Griggs Reservoir site, the script was written to separate moisture data for the surface and 1-ft depth. For the St. Francis data, a buffer zone was created $200 \mathrm{ft}$ from the outer edge of the rain garden, and soil moisture at the outer extent of the buffer was set to 1 percent. The buffer zone was needed to constrain the interpolation to the actual data points without generating erroneous data in areas outside the rain garden. The background soil moisture of 1 percent was selected after an iterative process determined that, at a distance of $200 \mathrm{ft}$, any soil moisture less than 10 percent had no effect on the interpolations at the rain garden. For the Griggs data, the five background sensors outside the rain garden were used to set the moisture level in the buffer.

ArcGIS ModelBuilder (Esri, Redlands, California) was used to create a raster surface by means of the Spline-withBarriers tool. The soil-moisture data were the input point data, and the buffer points were used as the barrier (where interpolation stops). The Spline tool interpolates estimated values by using a mathematical function that minimizes overall surface curvature, resulting in a smooth surface that exactly matches the input data points. The Spline-with-Barriers tool uses a similar method that allows discontinuities, which were controlled by the input and buffer data. The resultant raster surface was then clipped to the extent of the rain garden.

The procedure was modified to run as an automated process for each time step. For the St. Francis site, the animation for each depth level was created from 187 separate images in hourly time steps from September 5 at 00:00 to September 13 at 07:00 coordinated universal time (UTC). For the Griggs site, the animation for each depth is created from 266 separate images in 30-minute time steps from December 7 at 00:00 to December 12 at 13:00 eastern standard time (EST).

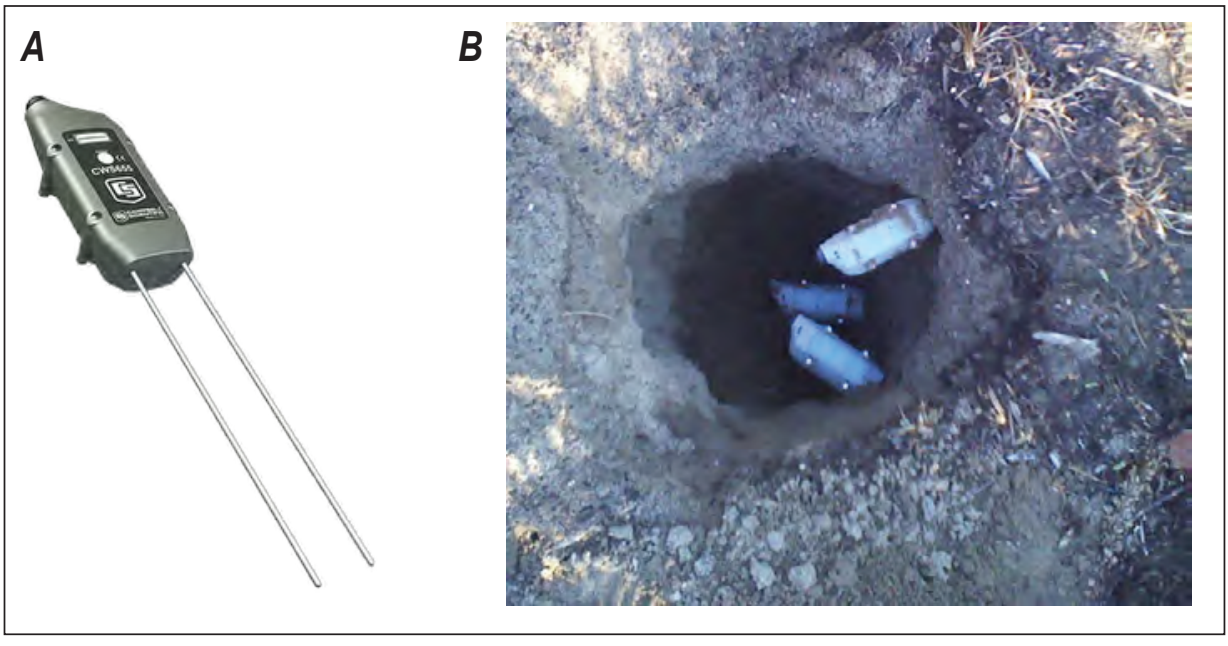

Figure 5. $\quad A$, Wireless soil-moisture probe. $B$, a nest of moisture sensors installed at three depths. 


\section{Data and Visualization}

The data from the St. Francis and Griggs Reservoir sites are shown in visualizations 1 and 2, respectively. The color ramp used for the visualizations is the same for each image: red (the starting point) represents a volumetric soil moisture of 10 percent; the ramp extends to blue, which represents a moisture of 50 percent (a value not exceeded at either site). The location of each soil-moisture sensor is represented on the plan views by a small dot. Occasionally, the wireless sensors lost contact with the data logger, resulting in a loss of data; in the animation, an out-of-contact sensor disappears from the diagram during time of data loss so that it is evident which sensors are being used to produce the image.

\section{St. Francis Site, Cincinnati}

The visualization for the St. Francis site (vis. 1) shows two separate precipitation events separated by about 2 days. The first event, totaling 0.24 in. of precipitation, started on September 5, 2012, at 20:50 UTC and lasted until 22:10 UTC the same day. A total of 160 cubic feet $\left(\mathrm{ft}^{3}\right)$ of water flowed into the upper rain garden via the inflow culvert (table 1). No measurable flow moved from the upper rain garden to the lower rain garden, and there was no measurable flow leaving the lower rain garden. The second event, totaling $1.47 \mathrm{in}$. of precipitation, started on September 8 at 04:15 and lasted until 17:30 the same day. A total of $920 \mathrm{ft}^{3} \mathrm{of}$ water flowed into the upper rain garden via the inflow culvert. A total of $660 \mathrm{ft}^{3}$ flowed into the lower rain garden at the inlet, and $120 \mathrm{ft}^{3}$ was measured at the outlet.

Visualization 1 consists of four diagrams. Diagrams A, $\mathrm{B}$, and $\mathrm{C}$ are plan views of the lower rain garden at the three sensor depths, $0.5 \mathrm{ft}(\mathrm{A}), 1 \mathrm{ft}(\mathrm{B})$ and $2 \mathrm{ft}(\mathrm{C})$. Diagram D is a graph showing the cumulative precipitation measured at the site. Although the inflow culvert discharges only to the surface of the rain garden, the location of the culvert is represented by the pipelike image in each plan view. The location of the surface overflow grate is represented by a gray box in each plan view. No surface overflows occurred during these events.

Prior to the first precipitation event, the red and orange colors in visualization 1 (A and $\mathrm{B}$ ) show that the soils at 0.5and 1-ft depths were relatively dry; the moisture (yellow and blue colors) at the $2 \mathrm{ft}$ depth (C) was the result of antecedent conditions. There was no significant change in soil-moisture levels at any depth during the first precipitation event, a result consistent with there being no inflow into the lower rain garden (table 1). Yellow, green, and then blue colors appear at the $0.5-\mathrm{ft}$ depth after the second precipitation event; the delay reflects the time it took for the runoff to move across the land, into and through the upper rain garden, and from the culvert as discharge into the lower rain garden. Although 1.47 in. of rain fell, the soil moisture at the 0.5 - and 1-ft depths increased significantly only near the inflow culvert. Higher moisture content may have occurred at the 1 -ft depth directly beneath the inflow culvert but, owing to signal loss with the wireless unit, no data were recorded for portions of this event. Notably, most of the soil at the 1-ft depth remained relatively dry (throughout the visualization), even as the moisture content at the $0.5-\mathrm{ft}$ depth increased slightly throughout the garden. Similarily, the greatest moisture content at the 2 - $\mathrm{ft}$ depth was beneath the inflow culvert, but there was an increase in moisture throughout the rain garden at the 2-ft depth.

Thus, visualization 1 shows that as water flowed from the upper rain garden, the soil moisture in the lower rain garden increased near the inflow culvert and moved to the lower depths. The moisture then spread laterally throughout the rain garden at the 2-ft depth. The infiltration capacity available at the ends of the upper 1- to $1.5-\mathrm{ft}$ of the rain garden away from the inflow culvert was not being utilized, even during a precipitation event that produced nearly $1.5 \mathrm{in}$. of rain. This visualization also shows how quickly soil moisture decreased in the top two layers after the end of the precipitation event. At 24 hours after the precipitation stopped, the soil moisture at 0.5 -ft and 1 -ft depths had nearly returned to pre-event conditions; at the 2-ft depth, the rain garden continued to dry over the next few days.

Table 1. Precipitation and flow-volume totals at St. Francis site, September 2012.

[UTC, coordinated universal time]

\begin{tabular}{lcccccc}
\hline Event & $\begin{array}{c}\text { Start } \\
\text { UTC }\end{array}$ & $\begin{array}{c}\text { End } \\
\text { UTC }\end{array}$ & $\begin{array}{c}\text { Precipitation } \\
\text { total, } \\
\text { inches }\end{array}$ & $\begin{array}{c}\text { Upper } \\
\text { Inflow, } \\
\text { cubic feet }\end{array}$ & $\begin{array}{c}\text { Lower } \\
\text { Inflow, } \\
\text { cubic feet }\end{array}$ & $\begin{array}{c}\text { Lower } \\
\text { outflow, } \\
\text { cubic feet }\end{array}$ \\
\hline 1 & $9 / 5 @ 20: 50$ & $9 / 5 @ 22: 10$ & 0.24 & 160 & 0 & 0 \\
2 & $9 / 8 @ 04: 15$ & $9 / 8 @ 17: 30$ & 1.47 & 920 & 660 & 120 \\
\hline
\end{tabular}




\section{Griggs Reservoir Site, Columbus}

The visualization for the Griggs site (vis. 2) shows two separate precipitation events separated by about 2 days. The first event, totaling 0.92 in. of precipitation, started on December 7, 2012, at 00:35 EST and lasted until 11:20 EST the next day. A total of 17,800 $\mathrm{ft} 3$ of water flowed into the rain garden via the inflow culverts (table 2). No measurable flow left the rain garden. The second event, totaling $0.37 \mathrm{in}$. of precipitation, started on December 9 at 12:45 EST and lasted until 07:00 the next day. A total of 7,400 $\mathrm{ft} 3$ of water flowed into the rain garden via the inflow culverts. Again, no measurable flow left the rain garden.

Visualization 2 consists of three diagrams, two plan views of the rain garden using data from the soil-moisture probes at the surface (A) and 1-ft depth (B), plus a graph of cumulative precipitation at the site $(\mathrm{C})$. The two inflow culverts are at the bottom of the diagram (south end of the rain garden), and the overflow grate and outflow pipe are in the middle of the narrow section of the rain garden. There was no surface overflow during these events.

Prior to the first precipitation event, the soil moisture was low (represented by orange) throughout the narrow end of the rain garden; the wider portion of the garden nearer the inflow culverts had higher soil moisture (yellow) with the highest moisture (light blue) in the area adjacent to the retaining wall (opposite the inflow pipes). As inflow occured, the soil moisture at the south end of the garden increased, while the increase in soil moisture in narrow section of the garden was less. As the garden began to dry, the soil moisture in the area along the retaining wall continued to remain higher than that in the rest of the garden.

Thus, visualization 2 shows that as water flows into the rain garden, the soil moisture builds up near the inflow and concentrates along the edge adjacent to the retaining wall. The moisture does not spread to the narrow section of the garden, thus the infiltration capacity in this area of the rain garden is not being utilized. This visualization also shows how quickly the rain garden returns to pre-event conditions.

\section{References Cited}

Dietz, M.E., 2007, Low impact development practices: a review of current research and recommendations for future directions: Water Air Soil Pollut, 186: 351-363

Lerch, N.K., Hale, W.F., and Lemaster, D.D., 1982, Soil survey of Hamilton County, Ohio: U.S. Department of Agriculture, Soil Conservation Service, 219 p., 56 sheets, scale $1: 15,840$.

Ohio Geographically Referenced Information Program, 2007, Ohio Statewide Imagery Program, Putnam County: Accessed March 13, 2008, at http://ogrip.oit.ohio.gov/.

Sauer, V.B., and Turnipseed, D.P., 2010, Stage measurement at gaging stations: U.S. Geological Survey Techniques and Methods book 3, chap. A7, 45 p. (Also available at $h t t p: / /$ pubs.usgs.gov/tm/tm3-a7/.)

Kilpatrick, F.A., and Schneider, V.R., 1983, Use of flumes in measuring discharge: U.S. Geological Survey Techniques of Water-Resources Investigations, book 3, chap. A14, 46 p. (Also available at http://pubs.usgs.gov/twri/twri3-a14/.)

Table 2. Precipitation and flow-volume totals at Griggs site, December 2012.

[EST, eastern standard time]

\begin{tabular}{cccccc}
\hline Event & $\begin{array}{c}\text { Start } \\
\text { EST }\end{array}$ & $\begin{array}{c}\text { End } \\
\text { EST }\end{array}$ & $\begin{array}{c}\text { Precipitation } \\
\text { total, inches }\end{array}$ & $\begin{array}{c}\text { Inflow, } \\
\text { cubic feet }\end{array}$ & $\begin{array}{c}\text { Outflow, } \\
\text { cubic feet }\end{array}$ \\
\hline 1 & $12 / 7 @ 0: 35$ & $12 / 8 @ 11: 20$ & 0.92 & 17,800 & 0 \\
2 & $12 / 9 @ 12: 45$ & $12 / 10 @ 07: 00$ & 0.37 & 7,400 & 0 \\
\hline
\end{tabular}






\section{$\frac{\mathbb{2}}{3}$}

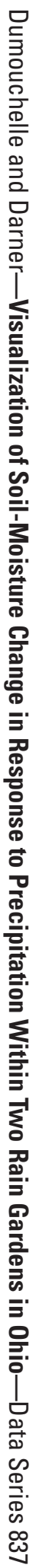

